\title{
Matka kielten ja kirjallisuuksien moninaiseen maailmaan
}

Arja Nurmi, Saija Isomaa \& Päivi Pahta (toim.): Kielten ja kirjallisuuksien mosaiikki: näkökulmina valta, periferia ja arki, Helsinki: SKS, 2019, 338 s.

Arja Nurmen, Saija Isomaan ja Päivi Pahtan toimittama kokoelma pureutuu laajasti erilaisiin kielten, kirjallisuuksien ja kulttuurien moninaisuuteen liittyviin aiheisiin niin historiallisesti kuin nyky-yhteiskunnassakin. Kirjan nimen mukaisesti painopisteinä ovat kielten väliset valtasuhteet, vähemmistökielten ja -kulttuurien asema yhteiskunnassa sekä kielten moninaisuuden vaikutukset arjen tilanteisiin. Kielten, kirjallisuuksien ja kulttuurien moninaisuutta kuvataan mosaiikkina, jonka palasten kirjoa tarkastellaan kielentutkimuksen, kirjallisuudentutkimuksen ja käännöstieteen näkökulmista.

Teos jakautuu neljään temaattiseen osioon, joiden sisältöä toimittajat pohjustavat johdannossaan. Ensimmäisessä osiossa käsitellään monikielisyyttä ja kielten moninaisuutta yhteiskunnan ja kirjallisuusinstituution näkökulmasta. Jukka Havu käsittelee artikkelissaan nationalismin käsitteen suhdetta kielten moninaisuuteen eri puolilla maailmaa niin historiallisesti kuin nykypäivänäkin. Hän käyttää esimerkkeinä erilaisia tilanteita, joissa nationalistinen kielipolitiikka on ollut osana kansallisia konflikteja. Heidi Grönstrand, Ralf Kauranen, Olli Löytty ja Kukku Melkas puolestaan pureutuvat Suomessa muulla kuin suomen tai ruotsin kielellä julkaisevien kirjailijoiden asemaan Suomen kirjallisuuden kentällä. Artikkelissa käsitellään myös monikielisen, kieli- ja kulttuurirajoja ylittävän kirjallisen tuotannon roolia niin kansallisesti kuin kansainvälisestikin. Arja Nurmen artikkelin keskiössä ovat erilaiset, niin kaunokirjallisissa kuin asiateksteissäkin hyödynnettävät monikieliset käytänteet ja niiden kääntäminen.

Toisessa osiossa kirjoittajien huomio siirtyy monikielisyyden historialliseen kontekstiin. Sekä Jukka Tyrkkö että Kaisa Koskinen käyttävät artikkeleissaan 1800-luvun Tamperetta esimerkkinä monikielisyyden ilmentymistä ja haasteista. Tyrkön artikkeli käsittelee kielitaidon vaikutusta ihmisen sosiaaliseen ja yhteiskunnalliseen asemaan, ja hän käyttää esimerkkitapauksena 1800-luvulla teollistuvalle Tampereelle saapuneita ulkomaalaisia työntekijöitä. Koskinen puolestaan perehtyy kääntämisen rooliin Tampereen kaupunginvaltuuston 
kielipolitiikan kehityksessä 1800-luvun lopulla suomen kielen vallatessa alaa ruotsilta.

Kolmannen osion teemoja ovat monikielisyys ja kielellinen moninaisuus yhtäältä suomalaisissa kouluissa ja toisaalta monikielisten ihmisten ja perheiden arjessa. Sirkku Latomaa tarkastelee monikielitietoisuuden kehitystä suomalaisissa opetussuunnitelmissa 1980-luvulta nykypäivään. Olga Nenonen pohtii suomea ja venäjää puhuvien kaksikielisten ihmisten kielivalintoja ja vertailee kaksikielisten lasten kielitaidon kehittymistä yksikielisten suomen- ja venäjänkielisten lasten kehitykseen. Marja Kivilehto tutustuu peruskoulun oppikirjojen kääntämiseen suomesta ruotsiksi käyttäen esimerkkeinä kahta historian oppikirjaa. Keskiössä ovat opetuksen tasa-arvon toteutuminen sekä käännettyjen oppikirjojen vaikutus oppilaan kielellisen identiteetin rakentumiseen.

Neljännessä osiossa teemana puolestaan on kielen suhde yksilön identiteettiin sekä kieltenväliset valta-asetelmat. Hanna Mattila käsittelee saamelaisen kieli- ja kulttuuri-identiteetin ilmentymistä saamelaisessa nykyrunoudessa. Myös Sari Kivistö keskittyy artikkelissaan nykyrunouteen, tällä kertaa latinan käytön elvyttäjänä. Hän pohtii erilaisia tapoja, joilla kuollutta kieltä voidaan elvyttää. Leena Eilittä tutkii omassa artikkelissaan maailmankirjallisuuden käsitteen merkityksiä ja kehitystä 1800-luvulta nykypäivään.

Kokoelmassa käsitellään varsin laaja-alaisesti erilaisia kielten, kirjallisuuksien ja kulttuurien moninaisuuteen liittyviä aiheita, ja valtaisan mosaiikin paloja nivotaan yhteen. Monia artikkeleista yhdistää ajatus yhteiskunnallisesta muutoksesta kieliin ja monikielisyyteen suhtautumisessa sekä vähemmistökielten ja -kulttuurien muuttuvasta asemasta. Niin opetussuunnitelmissa kuin kirjallisuudentutkimuksen käsitteissäkin on nähtävissä merkkejä yhteiskunnallisen elämän globaalistumisesta. Toisaalta kielten ja kulttuurien moninaisuuden syvemmän tiedostamisen rinnalla esiintyy myös lisääntyvää kansallismielisyyttä ja kielteistä suhtautumista kielten ja kulttuurien moninaisuuteen.

Koska kokoelman kattaus on laaja, ei yksittäisiin aiheisiin ole sen puitteissa ollut mahdollista pureutua kovin syvällisesti. Kirjoittajat tarjoavat ajatuksiaan sellaisista aiheista, joihin tämän teoksen sivut eivät ole riittäneet. Toimittajat kuvailevat johdannossa Suomessa puhuttavien vähemmistökielten kirjoa ja toteavat monien vähemmän puhuttujen kielten jäävän yhteiskunnassa usein periferiaan. Monet vähemmistökielet jäävät tässäkin tapauksessa pienelle huomiolle kansalliskieliimme suomeen ja ruotsiin verrattuna. Suomalaisen nyky-yhteiskunnan käsittelyssä syvempään tarkasteluun pääsevät Nenosen artikkelissa venäjä ja Mattilan artikkelissa saamen kielet.

Rajaukset omalta osaltaan kuvastavat kielten moninaisuuden mukanaan tuomia haasteita. Esimerkiksi muun kuin suomenkielisen oppimateriaalin saatavuuden osalta Kivilehto mainitseekin olemassa olevan tutkimuksen rajallisuuden ja toteaa oman historian oppikirjojen ruotsinnosten käsittelynsä 
olevan vain pintaraapaisu. Lisäksi Mattila mainitsee yhdeksi saamenkielisen kirjallisen tuotannon eduista mahdollisuuden käyttää teoksia kielen ja kirjallisuuden oppimateriaaleina. Muiden vähemmistökielten osalta asiaa ei syvemmin käsitellä. Pääosin keskustelu kielten moninaisuudesta kulkee siis yleisellä tasolla käyttäen joitain yksittäisiä kieliä esimerkkeinä. Kokoelma osoittaakin onnistuneesti, miten laajasta aiheesta on kysymys ja miten monia uusia tutkimuspolkuja mosaiikin palasista olisi vielä mahdollista avata.

\section{Laura Ekberg}

